\title{
The Melanin Biosynthesis Stimulating Compounds Isolated from the Fruiting Bodies of Pleurotus citrinopileatus
}

\author{
Tian-Xiao Meng ${ }^{1}$, Chao-Feng Zhang ${ }^{1,2}$, Tomofumi Miyamoto ${ }^{3}$, Hiroya Ishikawa ${ }^{4}$, Kuniyoshi Shimizu ${ }^{{ }^{*}}$, \\ Shoji Ohga ${ }^{1}$, Ryuichiro Kondo ${ }^{1}$ \\ ${ }^{1}$ Department of Agro-Environmental Sciences, Faculty of Agriculture, Kyushu University, Fukuoka, Japan; ${ }^{2}$ Research Department of \\ Pharmacognosy, China Pharmaceutical University, Nanjing, China; ${ }^{3}$ Graduate School of Pharmaceutical Sciences, Kyushu University, \\ Fukuoka, Japan; ${ }^{4}$ Department of Nutrition and Health Science, Faculty of Human Environmental Science, Fukuoka Women's University, \\ Fukuoka, Japan. \\ Email: ${ }^{*}$ shimizu@agr.kyushu-u.ac.jp
}

Received June $14^{\text {th }}, 2012$; revised July $19^{\text {th }}, 2012$; accepted July $30^{\text {th }}, 2012$

\begin{abstract}
In the course to find a stimulating compound for melanin biosynthesis, which should be useful for a gray and a white hair-preventive agent or tanning agent, we evaluated the effects of the methanol extract from mushroom of Pleurotus citrinopileatus on melanin production in B16 melanoma cells without theophylline. Activity-guided fractionation led to isolate myo-inositol (3) and D-mannitol (4) as the stimulating compounds on melanin production in B16 melanoma cells. Also, ergosterol (1), uracil (2), and D-glucose (5) have been isolated from the methanol extract of P. citrinopileatus and showed no effect on melanin production in B16 melanoma cells. These results indicated that myo-inositol (3) and Dmannitol (4) are potential candidates that could be useful such as a gray and a white hair-preventive agent or tanning agent.
\end{abstract}

Keywords: Pleurotus citrinopileatus; myo-Inositol; D-Mannitol; Melanin Stimulating Activity; White Hair-Preventive Agent; Tanning Agent

\section{Introduction}

Mushrooms are a nutritionally functional food and a source of physiologically beneficial medicines. Fruiting bodies of some wild and cultivatable mushrooms contain medicinal compounds that are used in traditional medicines and cosmetics. There are numerous potential medicinal products from mushrooms that could be used in cosmeceuticals (products applied topically, such as creams, lotions, and ointments) or nutricosmetics (products that are ingested orally). But, there are numerous mushroom species that are untested, undescribed, or not yet cultivatable and that have huge potential for use in the cosmetic industry. Some fungi are also used in bio-transformation, and products such as lactic acid and ceramides could potentially be used in cosmetics $[1,2]$.

Pleurotus citrinopileatus is an edible mushroom (Synonymy: P. cornucopiae, P. cornucopiae var. citrinopileatus) belonging to the genus Pleurotus, Pleurotaceae family. The name of this mushroom in English is golden oyster mushroom, tamogitake in Japanese, yuhuangmo in Chinese, goldenseed in Korean, and weishenga limonaya in Russian. A half dozen recent studies have focused on

"Corresponding author. the cultivation of $P$. citrinopileatus for its numerous multifunctional biological activities, such as melanin biosynthesis inhibitory activity, antioxidant, antibacterial, and antihyaluronidase activities [2,3]. However, there are a limited number of previous studies on the chemical composition, and there have been a few of reports identifying the lectin, peptide and protein from water extracts of $P$. citrinopileatus [4,5].

Skin pigmentation results from melanin synthesis by melanocytes and is caused by exposure to UV radiation. Tyrosinase is a key enzyme of melanin synthesis that catalyzes three different reactions: the hydroxylation of tyrosine to 3,4-dihydroxyphenylalanine (DOPA), the oxidation of DOPA to DOPA-quinone, and the oxidation of 5,6-dihydroxyindole (DHI) to indole-quinone [6]. In the absence of thiols DOPA-quinone changes to DOPA chrome and then to DHI or indole 5,6-quinone 2-carboxy-lic acid (DHICA). Broadly, there are two further steps in this melanogenic pathway, one involves tyrosinase related protein-2 (TRP-2; DOPA chrome tautomerase) which catalyzes the conversion of DOPA chrome to DHICA, and the other involves TRP-1 (DHICA oxidase) which catalyzes the oxidation of DHICA [7,8]. There are several signal pathways for enhancing melanin production. 
The cAMP-mediated pathway is a well known melanin synthesis cascade. $\alpha$-melanocyte stimulating hormone $(\alpha$ MSH), prostgland-in E2 (PGE2), and adrenocorticotropic hormone $(\mathrm{ACTH})$ activate the cAMP-mediated pathway $[9,10]$.

Human skin is repeatedly exposed to ultraviolet radiation (UVR) that influences the function and survival of many cell types and is regarded as the main causative factor in the induction of skin cancer. It has been traditionally believed that skin pigmentation is the most important photo-protective factor, since melanin, besides functioning as a broadband UV absorbent, has anti-oxidant and radical scavenging properties. Besides, many epidemiological studies have shown a lower incidence for skin cancer in individuals with darker skin compared to those with fair skin. Skin pigmentation is of great cultural and cosmetic importance. In light of the increasing incidence for UV induced skin cancer and the progressive depletion of the ozone layer, which contrasts to public perception of a tan as being healthy, a better understanding of the role of melanin in preventing UV induced DNA damage and malignant transformation of skin cells would be more than desirable [11]. Melanin containing tissues have been located in various parts of the human body outside the skin complex, including in the heart, lungs, liver, brain [12], lymphocytes [13], and inner ear [14]. Melanin is a pigment that gives color to the skin, eyes, and hair. Lack of melanin pigmentation occurs principally due to regional lack of melanocytes (e.g. piebaldism or vitiligo) or to the genetic transmission of mutations in pigment related genes that give rise to hypopigmentation (e.g. albinism) when inherited in a homozygous form. There are several forms of oculocutaneous albinism [15]. Skin lightening or whitening (leukoderma, hypopigmentation) is most commonly the result of decreased melanin content in the skin (hypomelanosis) [16]. Increase of epidermal turnover can also induce hypomelanosis. Hypomelanosis may affect hair color. Canities means a generalized loss of hair color, whereas poliosis refers to localized hypomelanosis involving a tuft of hair or a few hairs in the eyebrows or eyelashes [16].

In our preliminary screening, we have found that the methanol extract of $P$. citrinopileatus showed the stimulating effects on melanin formation in B16 melanoma cells. We investigate the melanin biosynthesis stimulatory effect of the methanol extract from the mushroom of $P$. citrinopileatus on B16 melanoma cells in order to identify potential melanin producing candidates, which are useful such as skin-tanning and white hair-preventive cos metics.

\section{Materials and Methods}

\subsection{General Experimental Procedure}

Column chromatography was performed by silica gel
(Wakogel C-200 particle size 75 - $150 \mu \mathrm{m}$; Wako Pure Chemical Industries, Co., Ltd., Japan). Thin layer chromatography (TLC) was carried out using Merck precoated silica gel $60 \mathrm{~F}_{254}$ plates $(0.25 \mathrm{~mm}$, Merck \& Co., Inc., Darmstadt, Germany) and spots were detected with $\mathrm{I}_{2}$ detection and under UV light. The compound $\mathbf{1}$ was isolated by preparative high performance liquid chromatography (HPLC) using a Waters TM 600 Controller, Waters TM 486 Tunable Absorbance Detector and Waters 600 Multi-solvent Delivery System (Japan Water Co., Ltd., Japan). The absorbance was measured by Tecan Spectra microplate reader (Tecan Japan Co., Ltd., Japan) and UV/VIS Spectrometer V-530 (JASCO Co., Japan). Preparative column using Inertsil preparative ODS column $(20 \mathrm{~mm}$ i.d. $\times 250 \mathrm{~mm})$ from GL Sciences (GL Sciences Inc., USA).

\subsection{Chemicals}

Dimethylsulfoxide (DMSO), potassium hydroxide solution $(\mathrm{NaOH})$, hydrochloric acid $(\mathrm{HCl})$ and sodium hydrogen carbonate $\left(\mathrm{NaHCO}_{3}\right)$ were purchased from Wako (Wako Pure Chemical Industries, Ltd., Japan). Thiazolyl blue tetrazolium bromide (MTT) was obtained from Sigma (Sigma-Aldrich Co., USA). Qualified fetal bovine serum (FBS) was obtained from Gibco ${ }^{\circledR}$ (Life Technologies Co., USA). Ethylene diamine tetraacetic acid (EDTA) was obtained from Dojindo (Dojindo Molecular Technologies, Inc., Japan). Trypsin was obtained from Nihon Pharmaceutical (Nihon Pharmaceutical Co., Ltd., Japan). Eagle's minimal essential media (EMEM) and Glutamine were purchased from Nissui (Nissui Pharmaceutical Co., Ltd., Japan). Theophylline was obtained from Sigma (Sigma Chemical Co., USA).

\subsection{Mushroom Materials}

Fresh fruiting bodies of $P$. citrinopileatus were obtained from Tamogitake Pharmaceutics Co., Ltd. (Nagano, Japan). The fruiting bodies were cleaned to remove any residual materials and then freeze-dried. The milled freezedried P. citrinopileatus $(900.0 \mathrm{~g})$ were extracted with methanol $(2 \times 9.0 \mathrm{~L})$ at room temperature for one week and then filtered. The methanol extract was concentrated by a rotary evaporator. The yield of the methanol extract was $114.0 \mathrm{~g}(12.7 \%)$.

\subsection{Extraction and Isolation}

A portion of the methanol extract $(100.0 \mathrm{~g})$ was applied to a silica gel column (Wakogel C-200, $4.0 \mathrm{~kg} ; 19 \mathrm{~cm}$ i.d. $\times 50 \mathrm{~cm})$ and eluted with $n$-hexane/chloroform $(7: 3,5: 5$, 3:7, 0:10), ethyl acetate, acetone, ethanol and methanol (each $8.0 \mathrm{~L}$ ), followed by methanol/water $(50: 1,6.0 \mathrm{~L}$; 11:1, $2.0 \mathrm{~L} ; 8: 1,3.0 \mathrm{~L}$ ), affording eight fractions (Fr.1 to 
Fr.8). Based on TLC analysis, using $n$-hexane/chloroform (1:9), Fr.1 $(\mathrm{Rf}=0,0.21,0.34,0.41,0.62,0.72$, $0.82), \mathrm{Fr} .2(\mathrm{Rf}=0,0.17,0.28,0.34,0.62,0.69)$ and Fr.3 $(\mathrm{Rf}=0,0.17,0.28,0.34,0.62,0.69)$ were combined to yield Fr.1' (7.0 g). A portion of the Fr.1' (4.6 g) was applied to a silica gel column chromatography (Wakogel C200,900 g; $5.5 \mathrm{~cm}$ i.d. $\times 120 \mathrm{~cm}$ ) and eluted with $n$-hexane/ethyl acetate $(20: 1,15: 5,10: 10,0: 20$, each $1.5 \mathrm{~L})$, ethyl acetate/methanol (20:1, 15:5, 10:10, 0:20, each 1.5 L) to give eight fractions (Fr.1'-1 to Fr.1'-8). Fr.1'-4-2 (494 mg) was recrystallized from methanol to give compound 1 (401 mg). Fr.1'-7 (344 mg) was fractionation by preparative HPLC (Inertsil Prep-ODS column, $20 \mathrm{~mm}$ i.d. $\times 250 \mathrm{~mm}$ ) and retention time was $16.5 \mathrm{~min}$ to give compound $2(36 \mathrm{mg})$. Fr.1'-8 (1.0 g) was recrystallized from methanol to give compound 3 (42 mg). Fr.4 and Fr.5 were combined to Fr.4' (4.5 g), which was fractionated by silica gel column chromatography (Wakogel C-200, $4.0 \mathrm{~kg} ; 19 \mathrm{~cm}$ i.d. $\times 50 \mathrm{~cm}$ ) to obtain six fractions (Fr.4'-1 to Fr.4'-6). Fraction 4'-6 (1.0 g) of by silica gel column chromatography $(120 \mathrm{~cm} \times 6.0 \mathrm{~cm}$ i.d.; $n$-hexane/chloroform 2:8, 1:9, 0:10; chloroform/methanol 9:1, 8:2, 7:3, $6: 4,5: 5,4: 6,3: 7,2: 8,1: 9,0: 10$, each $1400 \mathrm{~mL}$ ) to obtain seven fractions (Fr.4'-6-1 to Fr.4'-6-7). Fraction 4'-6-5 $(182 \mathrm{mg})$ was recrystallized from methanol to give compound $4(54 \mathrm{mg})$. Fr. $6(3.0 \mathrm{~g})$ was fractionated by silica gel column chromatography $(120 \mathrm{~cm} \times 6.0 \mathrm{~cm}$ i.d.; chloroform/methanol 2:8, 1.5:8.5, 1:9, 0.5:9.5, 0:10, each $1400 \mathrm{ml})$ to obtain five fractions. Fr.6-3 (2.4 g) was recrystallized from methanol to give compound 5 ( $2.3 \mathrm{~g})$. The nuclear magnetic resonance (NMR, 400MHz, JEOL Ltd., Japan) and gas chromate-graphy mass spectrometry (GC-MS) (GC-17A/QP5050; Shimadzu Corporation Ltd., Japan) data of the isolating compounds (Figure 1) were compared with those of authentic samples and reference [17-24].

\subsection{Inhibitory Effect on Melanogenesis Using Cultured B16 Melanoma Cells}

\subsubsection{Determination of Melanin Content}

B16 melanoma, a mouse melanoma cell line producing melanin, was obtained from RIKEN Cell Bank. The cells were maintained in EMEM supplemented with $10 \%(\mathrm{v} / \mathrm{v})$ fetal bovine serum (FBS) and $0.3 \mathrm{mg} / \mathrm{ml}$ glutamine. The cells were incubated at $37^{\circ} \mathrm{C}$ in a humidified atmosphere of $5 \% \mathrm{CO}_{2}$. Confluent cultures of B16 melanoma cells were rinsed in phosphate buffered saline (PBS) and removed from the plastic using $0.25 \%$ trypsin $/ 0.02 \%$ EDTA. The cells were placed at a density of $1 \times 10^{5}$ cells/well and incubated for $24 \mathrm{~h}$ in media prior to being treated with the samples. After $24 \mathrm{~h}$, the media were replaced with $900 \mu \mathrm{L}(998 \mu \mathrm{L})$ of fresh media and $100 \mu \mathrm{L}(2 \mu \mathrm{L})$ of water (DMSO) was added with or without (control)
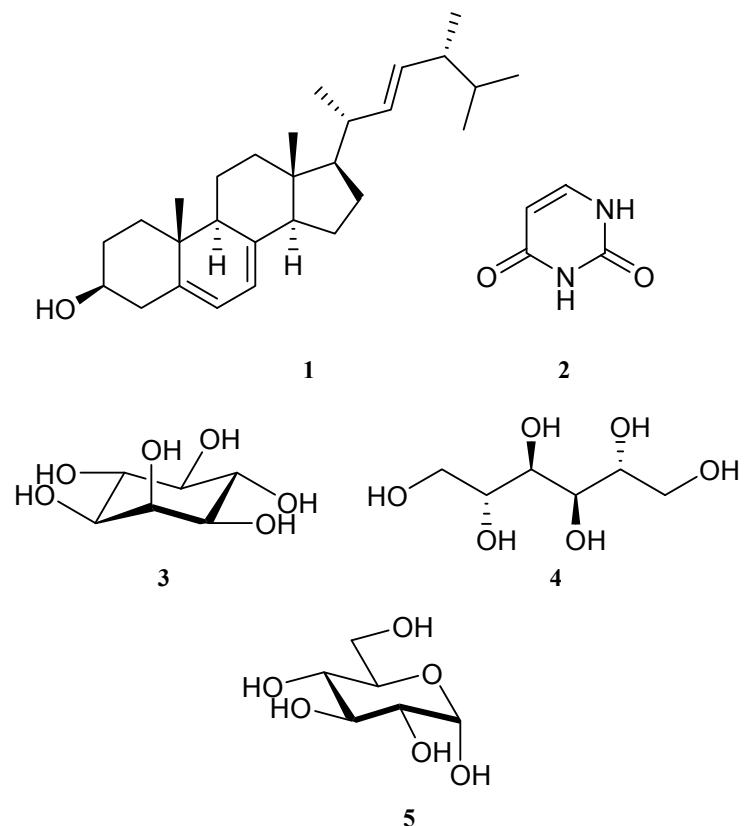

Figure 1. Structures of compounds 1 - 5 .

the test sample at various concentrations and its replicates were three times. The cells were incubated for an additional $48 \mathrm{~h}$, and then the medium was replaced with fresh medium containing each sample. After $24 \mathrm{~h}$, removing the medium and washing the cells, the cell pellet was dissolved in $1.0 \mathrm{~mL}$ of $1 \mathrm{~N} \mathrm{NaOH}$. The crude cell extracts were assayed using a micro plate reader at 405 $\mathrm{nm}$ to determine melanin content. The results from the samples were analyzed as a percent of the control culture. Theophylline was used as a positive control.

\subsubsection{Cell Viability}

Cell viability was determined by use of the microculture tetrazolium technique (MTT assay). A culture was initiated, and after incubation, $50 \mu \mathrm{L}$ of MTT in phosphate buffered saline $(5 \mathrm{mg} / \mathrm{mL})$ was added to each well. The plates were incubated for $4 \mathrm{~h}$. After removing the medium, formazan crystals were dissolved in $1.0 \mathrm{~mL}$ of $0.04 \mathrm{~N} \mathrm{HCl}$ and the absorbance was measured at $570 \mathrm{~nm}$ relative to $630 \mathrm{~nm}$.

\section{Results}

In present study, we evaluate the effect of the methanol extracts of the fruiting bodies of $P$. citrinopileatus on melanin production in B16 melanoma cells without theophylline. To search for melanin production stimulating compounds, we modified the assay using B16 melanoma cells. It should be noted that theophylline is usually added to medium for stimulating melanin production in B16 melanoma cells. Theophylline is known as an analogue of cAMP, which is a second messenger for mela- 
nin biosynthesis [25]. So, in our modified assay, theophylline was not added into medium, which is for finding melanin production stimulating compound. An index such as "mean of melanin content $(\%) /$ mean of cell viability (\%)" called as MC/CV value was applied for evaluating the stimulating activity of melanin production per cell induced by samples.

The methanol extracts were assayed by using B16 melanoma cells in order to evaluate the stimulation of melanin production and cell viability. The stimulating effect of methanol extracts on melanin production in B16 melanoma cells was shown at various concentrations (Table 1). At the concentration of $5.0 \mathrm{mg} / \mathrm{mL}$, the methanol extract showed melanin production stimulating activity per cell with $\mathrm{MC} / \mathrm{CV}$ value of 1.5 .

The methanol extract was subjected to a silica gel column (Wakogel C-200, $4.0 \mathrm{~kg} ; 19 \mathrm{~cm}$ i.d. $\times 50 \mathrm{~cm}$ ), gradient eluted with $n$-hexane/chloroform $(7: 3,5: 5,3: 7$, $0: 10$ ), ethyl acetate, acetone, ethanol and methanol (each $8.0 \mathrm{~L})$, followed by methanol/water $(50: 1,6.0 \mathrm{~L} ; 11: 1$, 2.0 L; 8:1, 3.0 L), affording eight fractions (Fr.1 to Fr.8). Fr.3 and Fr.4 showed (Table 2) higher melanin production stimulating activity with $\mathrm{MC} / \mathrm{CV}$ value of 4.0 and 4.4, respectively. Activity-guided fractionation of Fr.3 and Fr.4 led to the isolation of uracil (2), myo-inositol (3) and D-mannitol (4) as main components. Activity-guided fractionation of Fr.4 led to the isolation of D-mannitol as dominant component. Both of myo-inositol (3) $(12 \mathrm{mg} /$ $\mathrm{ml})$ and D-manntiol (4) $(18 \mathrm{mg} / \mathrm{ml})$ showed (Tables 3 and 4) potential melanin production stimulating activity with $\mathrm{MC} / \mathrm{CV}$ value of 1.6. Also, another weak activityguided fractionation of Fr.2 and Fr.6 led to ergosterol (1) and D-glucose (5). However, ergosterol (1), uracil (2), and D-glucose (5) showed no effect on melanin production in B16 melanoma cells (data not show). These re-

Table 1. The effect of methanol prepared extract from the fruiting bodies of $P$. citrinopileatus on B16 melanoma cells.

\begin{tabular}{cccc}
\hline $\begin{array}{c}\text { Concentration } \\
(\mathrm{mg} / \mathrm{mL})\end{array}$ & $\begin{array}{c}\text { Melanin content } \\
(\% \text { vs. control })\end{array}$ & $\begin{array}{c}\text { Cell viability } \\
\text { (\% vs. control) }\end{array}$ & $\mathrm{MC} / \mathrm{CV}^{\mathrm{b}}$ \\
\hline 0.0 & $100.0 \pm 1.5$ & $100.0 \pm 3.2$ & 1.0 \\
0.3 & $92.6 \pm 5.5$ & $92.7 \pm 4.8$ & 1.0 \\
0.6 & $96.5 \pm 3.6$ & $97.9 \pm 0.5$ & 1.0 \\
1.3 & $86.0 \pm 2.4^{* *}$ & $93.6 \pm 4.7$ & 0.9 \\
2.5 & $95.3 \pm 0.7^{*}$ & $77.3 \pm 6.1^{*}$ & 1.2 \\
5.0 & $88.3 \pm 1.8^{* *}$ & $60.4 \pm 4.4^{* *}$ & 1.5 \\
$\begin{array}{c}\text { Theophylline } \\
(0.01)\end{array}$ & $138.6 \pm 3.4^{* *}$ & $96.1 \pm 3.4$ & 1.4 \\
\hline
\end{tabular}

Data presented as means \pm R.S.D. $(\mathrm{n}=3) ;{ }^{*} \mathrm{p}<0.05,{ }^{* *} \mathrm{p}<0.01$, Significantly different from control group. ${ }^{a}$ Positive control for melanin stimulating activity. ${ }^{\mathrm{b}} \mathrm{MC} / \mathrm{CV}$ indicate "mean of melanin content (\%)/mean of cell viability (\%)".
Table 2. The effect of each fractions obtained from methanol extract from the fruiting bodies of $P$. citrinopileatuson B16 melanoma cells.

\begin{tabular}{ccccc}
\hline Samples & $\begin{array}{c}\text { Concentration } \\
(\mathrm{mg} / \mathrm{mL})^{\mathrm{b}}\end{array}$ & $\begin{array}{c}\text { Melanin } \\
\text { content } \\
(\% \text { vs. } \\
\text { control })\end{array}$ & $\begin{array}{c}\text { Cell } \\
\text { viability } \\
\text { (\% vs. } \\
\text { control })\end{array}$ & $\mathrm{MC} / \mathrm{CV}^{\mathrm{c}}$ \\
\hline Control & 0.0 & $100.0 \pm 2.1$ & $100.0 \pm 2.7$ & 1.0 \\
Fr.1 & 0.4 & $103.5 \pm 7.4$ & $87.9 \pm 6.0^{*}$ & 1.2 \\
Fr.2 & 1.9 & $86.1 \pm 7.5$ & $35.3 \pm 1.8^{* *}$ & 2.4 \\
Fr.3 & 1.7 & $67.2 \pm 7.9^{*}$ & $16.8 \pm 3.4^{* *}$ & 4.0 \\
Fr.4 & 1.9 & $73.6 \pm 0.9^{*}$ & $16.6 \pm 1.5^{* *}$ & 4.4 \\
Fr.5 & 2.6 & $78.1 \pm 5.2^{*}$ & $26.8 \pm 0.8^{* *}$ & 2.9 \\
Fr.6 & 3.1 & $121.4 \pm 4.6^{*}$ & $58.5 \pm 4.5^{* *}$ & 2.1 \\
Fr.7 & 5.6 & $50.8 \pm 2.2^{* *}$ & $40.2 \pm 2.9^{* *}$ & 1.3 \\
Fr.8 & 4.9 & $51.7 \pm 0.7^{* *}$ & $18.3 \pm 1.0^{* *}$ & 2.8 \\
Theophylline & 0.01 & $138.6 \pm 3.4^{* *}$ & $96.1 \pm 3.4$ & 1.4 \\
\hline
\end{tabular}

Data presented as means \pm R.S.D. $(n=3) ;{ }^{*} \mathrm{p}<0.05,{ }^{* *} \mathrm{p}<0.01$, Signifi-

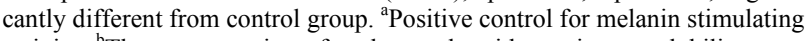
activity. ${ }^{\mathrm{b}}$ The concentration of each sample with maximum solubility were selected. ${ }^{\mathrm{c}} \mathrm{MC} / \mathrm{CV}$ indicate "mean of melanin content $(\%) /$ mean of cell viability (\%)".

Table 3. The effect of myo-inositol isolated from the fruiting bodies of $P$. citrinopileatus on B16 melanoma cells.

\begin{tabular}{cccc}
\hline Samples (mg/mL) & $\begin{array}{c}\text { Melanin content } \\
(\% \text { vs. control })\end{array}$ & $\begin{array}{c}\text { Cell viability } \\
\text { (\% vs. control) }\end{array}$ & $\mathrm{MC} / \mathrm{CV}^{\mathrm{b}}$ \\
\hline 0 & $100.0 \pm 2.2$ & $100.0 \pm 4.0$ & 1.0 \\
1 & $106.3 \pm 5.7$ & $92.8 \pm 2.5^{*}$ & 1.2 \\
2 & $103.8 \pm 2.9$ & $91.5 \pm 0.9^{* *}$ & 1.1 \\
5 & $101.9 \pm 2.9$ & $89.2 \pm 1.1^{* *}$ & 1.1 \\
9 & $110.1 \pm 3.8^{*}$ & $76.8 \pm 0.41^{* *}$ & 1.4 \\
18 & $111.4 \pm 5.8^{*}$ & $70.8 \pm 4.7^{* *}$ & 1.6 \\
\hline
\end{tabular}

Data presented as means \pm R.S.D. $(\mathrm{n}=3) ;{ }^{*} \mathrm{p}<0.05,{ }^{* *} \mathrm{p}<0.01$, Significantly different from control group. ${ }^{a}$ Positive control for melanin stimulating activity. ${ }^{\mathrm{b}} \mathrm{MC} / \mathrm{CV}$ indicate "mean of melanin content $(\%) /$ mean of cell viability (\%)".

sults indicated that myo-inositol (3) and D-mannitol (4) are potential candidates that could be useful, as a tanning and a white hair-preventive agent.

\section{Discussion}

As described above, skin pigmentation results from melanin synthesis by several enzymes such as tyrosinase in melanocytes and is caused by exposure to UV radiation. Outside of them, there are several pathways for enhanc- 
Table 4. The effect of D-mannitol isolated from the fruiting bodies of $P$. citrinopileatus on B16 melanoma cells.

\begin{tabular}{cccc}
\hline Sampes (mg/mL) & $\begin{array}{c}\text { Melanin content } \\
\text { (\% vs. control) }\end{array}$ & $\begin{array}{c}\text { Cell viability } \\
\text { (\% vs. control) }\end{array}$ & $\mathrm{MC} / \mathrm{CV}^{\mathrm{b}}$ \\
\hline 0 & $100.0 \pm 2.5$ & $100.0 \pm 1.7$ & 1.0 \\
2 & $101.3 \pm 10.1$ & $88.5 \pm 7.5$ & 1.1 \\
3 & $112.9 \pm 4.3$ & $104.0 \pm 2.0^{* *}$ & 1.1 \\
6 & $111.2 \pm 3.5$ & $94.4 \pm 5.1^{* *}$ & 1.2 \\
25 & $116.1 \pm 6.3^{*}$ & $86.0 \pm 2.8^{* *}$ & 1.3 \\
\hline Theophylline & & & \\
\hline 2 & $106.3 \pm 2.8^{*}$ & $66.0 \pm 3.1^{* *}$ & 1.6 \\
\hline
\end{tabular}

Data presented as means \pm R.S.D. $(\mathrm{n}=3) ;{ }^{*} \mathrm{p}<0.05,{ }^{* *} \mathrm{p}<0.01$, Significantly different from control group. ${ }^{\mathrm{a}}$ Positive control for melanin stimulating activity. ${ }^{b} \mathrm{MC} / \mathrm{CV}$ indicate "mean of melanin content $(\%) /$ mean of cell viability (\%)".

ing melanin production. The cAMP-mediated pathway is a well-known melanin synthesis cascade and $\alpha-\mathrm{MSH}$, prostaglandin E2 (PGE2), and adrenocorticotropic hormone $(\mathrm{ACTH})$ activate the cAMP-mediated pathway $[9,10]$.

On the other hand, a cGMP-mediated pathway can also increase melanin production. This pathway is activated by nitric oxide (NO), which is released by keratinocytes following UV-B irradiation. Protein kinase $\mathrm{C}$ (PKC) can activate tyrosinase. UV light might activate cell membrane bound phospholipase $\mathrm{C}$, and augmented diacylglycerol (DAG) can activate PKC [26].

Skin is a major candidate target of oxidative stress caused by reactive species (RS), including reactive oxygen species and reactive nitrogen species. RS are major and significant contributors to skin hyper pigmentation and skin aging. It is generally believed that agents having antioxidant activity show anti-aging, whitening, and antiinflammatory activities [27]. If free radicals are inappropriately processed in melanin synthesis, hydrogen peroxide $\left(\mathrm{H}_{2} \mathrm{O}_{2}\right)$ is generated, leading to the production of hydroxyl radicals $(\mathrm{HO} \cdot)$ and other reactive oxygen species (ROS) [28]. Oxidative stress may be induced by increasing the generation of ROS and other free radicals. UV radiation can induce the formation of ROS in skin such as singlet oxygen and superoxide anions, promoting biological damage in exposed tissues via ironcatalyzed oxidative reactions. These ROS enhance melanin biosynthesis, damage DNA, and may induce proliferation of melanocytes [29]. Yamakoshi et al. [29] found evidence for a role of oxidative stress in the pathogenesis of skin disorders. It is known that ROS scavengers or inhibitors such as antioxidants may reduce hyperpigmentation. Additionally, superoxide dismutase (SOD, EC 1.15.1.1), which catalyzes the dismutation of the superoxide anion into hydrogen peroxide and molecular oxygen, is one of the most important antioxidative enzymes.

The myo-inositol (3) and D-mannitol (4) were known as hydroxyl radical scavengers [30], so should be concerned in radical pathway. Further, the two compounds showed no activity against ORAC, SOD like assay and DPPH (data not show). Considering the role of ROS and their effects against ROS, their mechanisms of the melanin production stimulating activity in B16 melanoma cells should be related with other factor such as cAMP signaling rather than their effects on ROS.

According to the increase of the elderly population, many people are afflicted with white hair. Thus, the market for hair-dye and anti-white hair agents are growing. White hair is caused by a genetic predisposition, aging, decrement of melanocytes by environmental stress, and decrement of the biosynthesis of melanin pigment, or melanogenesis [31,32]. Hair-dye agents are used for the treatment of white hair, and some anti-white hair agents are under development. However, there remain some problems with these agents, such as insufficient activity and side effects due to the dyes. Thus, there is a need for safer anti-white hair agents exhibiting satisfactory melanogenesis activity and white hair prevention [33]. Since a melanocyte reservoir exists in the human hair follicle [31], it is considered that stimulation and/or activation of melanocyte in the hair follicle is a prospective means to prevent white hair [33].

In addition, inositol 1,4,5-trisphosphate $\left(\mathrm{IP}_{3}\right)$ releases calcium from intracellular stores [34,35], signal transduction, stress, protection, hormonal homeostasis and cell wall biosynthesis in plants [36]. The functions and roles of myo-inositol in humans have been linked to bipolar disorder [37], production of L-chiro-inositol and D-chiroinositol in insulin action [38], multiple sclerosis [39], Alzheimer's disease [40] and regulation of the sorbitol pathway in diabetic patients [41]. Mannitol is used as a sweettasting bodying and texturing agent [42]. The complex of boric acid with mannitol is used in the production of dry electrolytic capacitors. It is an extensively used polyol for production of resins and surfactants [43]. Mannitol is used in medicine as a powerful osmotic diuretic (to increase the formation of urine in order to prevent and treat acute renal failure and also in the removal of toxic substances from the body) and in many types of surgery for the prevention of kidney failure (to alter the osmolarity of the glomerular filtrate) and to reduce dye and brain oedema (increased brain water content). Hypertonic mannitol can enhance the transport of drugs across the bloodbrain barrier for the treatment of life-threatening brain diseases [44]. Inhaled mannitol improves the hydration and surface properties of sputum in patients with cystic fibrosis [45]. Mannitol hexanitrate is a well-known vasodilator, used in the treatment of hypertension [46]. Mannitol is also a scavenger of hydroxyl radicals [30]. 


\section{Conclusion}

In this study, we found a new facet of biological activity of myo-inositol (3) and D-mannitol (4) isolated from $P$. citrinopileatus, stimulating activity of melanin production. Therefore, these compounds are potential candidates that could be useful as a gray and a white hair-preventive agent or a tanning agent.

\section{REFERENCES}

[1] K. D. Hyde, A. H. Bahkali and M. A. Moslem, "Fungi: An Unusual Source for Cosmetics," Fungal Diversity, Vol. 43, No. 1, 2010, pp. 1-9. doi:10.1007/s13225-010-0043-3

[2] T. X. Meng, H. Ishikawa, K. Shimizu, S. Ohga and R. Kondo, "Evaluation of Biological Activities of Extracts from the Fruiting Body of Pleurotus citrinopileatus for Skin Cosmetics," Journal of Wood Science, Vol. 57, No. 5, 2011, pp. 452-458. doi:10.1007/s10086-011-1192-Z

[3] T. X. Meng, S. Furuta, S. Fukamizu, R. Yamamoto, H. Ishikawa, E. T. Arung, K. Shimizu, S. Ohga and R. Kondo, "A Glucosylceramide with Antimicrobial Activity from the Edible Mushroom Pleurotus citrinopileatus," Journal of Wood Science, Vol. 58, No. 1, 2012, pp. 81-86. doi:10.1007/s10086-011-1213-y

[4] J. H. Janga, S. C. Jeonga, J. H. Kimb, Y. H. Leeb, Y. C. Jub and J. S. Leea, "Characterization of a New AntiHypertensive Angiotensin I-Converting Enzyme Inhibitory Peptide from Pleurotus cornucopiae," Food Chemistry, Vol. 127, No. 2, 2011, pp. 412-418.

[5] Y. Takakura, N. Oka, H. Kajiwara, M. Tsunashima, S. Usami, H. Tsukamoto, Y. Ishida and T. Yamamoto, "A Versatile Affinity Tag for Protein Purification and Immobilization," Journal of Biotechnology, Vol. 145, No. 4, 2010, pp. 317-322.

[6] V. J. Hearing and K. Tsukamoto, "Enzymatic Control of Pigmentation in Mammals," The Journal of the Federation of American Societies for Experimental Biology, Vol. 5, No. 14, 1991, pp. 2902-2909.

[7] I. J. Jackson, D. M. Chambers, K. Tsukamoto, N. G. Copeland, D. J. Gilbert, N. A. Jenkins and V. Hearing, "A Second Tyrosinase-Related Protein, TRP-2, Maps to and Is Mutated at the Mouse Slaty Locus," The EMBO Journal, Vol. 11, No. 2, 1992, pp. 527-535.

[8] P. Aroca, F. Solano, C. Salinas, J. C. Garcia-Borron and J. A. Lozano, "Regulation of the Final Phase of Mammalian Melanogenesis: The Role of Dopachrome Tautomerase and the Ratio between 5,6-Dihydroxyindole-2-carboxylic Acid and 5,6-Dihydroxyindole," European Journal of Biochemistry, Vol. 208, No. 1, 1992, pp. 155-163.

[9] E. Steingrímsson, N. G. Copeland and N. A. Jenkins, "Melanocytes and the Microphthalmia Transcription Factor Network," Annual Review of Genetics, Vol. 38, No. 1, 2004, pp. 365-411.

[10] R. Busca and R. Ballotti, "Cyclic AMP: A Key Messenger in the Regulation of Skin Pigmentation," Pigment Cell Research, Vol. 13, No. 2, 2000, pp. 60-69.

[11] M. Brenner and V. J. Hearing, "The Protective Role of
Melanin against UV Damage in Human Skin," Photochemistry and Photobiology, Vol. 84, No. 3, 2008, pp. 539549. doi:10.1111/j.1751-1097.2007.00226.x

[12] M. D. Altschule and Z. L. Hegedus, "Commentary: The Importance of Studying Visceral Melanins," Clinical Pharmacology and Therapeutics, Vol. 19, No. 2, 1976, pp. 124 134.

[13] H. P. Wassermann, "Studies on Melanin-Labelled Cells in the Human Skin Window," South African Journal of Laboratory and Clinical Medicine, Vol. 10, 1964, pp. 7681.

[14] A. S. Breathnach, "Extra-Cutaneous Melanin," Pigment Cell Research, Vol. 1, No. 4, 1988, pp. 234-237. doi:10.1111/j.1600-0749.1988.tb00421.x

[15] C. G. Summers, W. S. Oetting and R. A. King, "Diagnosis of Oculocutaneous Albinism with Molecular Analysis," American Journal of Ophthalmology, Vol. 121, No. 6, 1996, pp. 724-726.

[16] J. P. Ortonne and T. Passeron, "Melanin Pigmentary Disorders: Treatment Update," Dermatologic Clinics, Vol. 23, No. 2, 2005, pp. 209-226. doi:10.1016/i.det.2005.01.001

[17] D. B. Sgarbi, A. J. Silva, I. Z. Carlos, C. L. Silva, J. Angluster and C. S. Alviano, "Isolation of Ergosterol Peroxide and Its Reversion to Ergosterol in the Pathogenic Fungus Sporothrix schenckii," Mycopathologia, Vol. 139, No. 1, 1997, pp. 9-14. doi:10.1023/A:1006803832164

[18] A. Trigos and A. Ortega-Regules, "Selective Destruction of Microscopic Fungi through Photo-Oxidation of Ergosterol," Mycologia, Vol. 94, No. 4, 2002, pp. 563-568. doi: $10.2307 / 3761707$

[19] Y. S. Kim, I. K. Lee, S. J. Seok and B. S. Yun, "Chemical Constituents of the Fruiting Bodies of Clitocybe nebularis and Their Antifungal Activity," Mycobiology, Vol. 36, No. 2, 2008, pp. 110-113. doi:10.4489/MYCO.2008.36.2.110

[20] R. J. Abraham, J. Byrne, L. Griffiths and R. Koniotou,

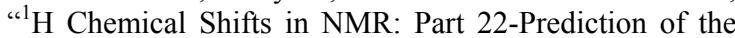
${ }^{1} \mathrm{H}$ Chemical Shifts of Alcohols, Diols and Inositols in Solution, a Conformational and Solvation Investigation," Magnetic Resonance in Chemistry, Vol. 43, No. 8, 2005, pp. 611-624. doi:10.1002/mrc.1611

[21] R. Jennemann, B. L. Bauer, H. Bertalanffy, R. Geyer, R. M. Gschwind, T. Selmer and H. Wiegandt, "Novel Glycoinositolphosphosphingolipids, Basidiolipids, from $\mathrm{Aga}$ ricus," European Journal of Biochemistry, Vol. 259, No. 2, 1999, pp. 331-338.

[22] S. Y. Hagiwara, M. Takahashi, Y. Shen, S. Kaihou, T. Tomiyama, M. Yazawa, Y. Tamai and M. Terazawa, "A Phytochemical in an Edible Tamogi-Take Mushroom (Pleurotus cornucopiae), D-Mannitol, Inhibits ACE Activity and Lowers the Blood Pressure of Spontaneously Hypertensive Rats," Bioscience Biotechnology and Biochemistry, Vol. 69, No. 8, 2005, pp. 1603-1605. doi:10.1271/bbb.69.1603

[23] A. Bagno, F. Rastrelli and G. Saielli, "Prediction of the ${ }^{1} \mathrm{H}$ and ${ }^{13} \mathrm{C}$ NMR Spectra of $\alpha$-D-Glucose in Water by DFT Methods and MD Simulations," The Journal of Organic Chemistry, Vol. 72, No. 19, 2007, pp. 7373-7381. 
[24] H. Asaoka, " ${ }^{1} \mathrm{H}-$ and ${ }^{13}$ C-N.M.R. Spectroscopy of $\alpha$-DGlucose and $\alpha$-D-Mannose with Boron (III) Oxide as Shift Reagent," Carbohydrate Research, Vol. 118, 1983, pp. 302-307. doi:10.1016/0008-6215(83)88060-4

[25] A. Hussein, N. Al-Wadei, T. Takahashi and H. M. Schuller, "Theophylline Stimulates cAMP-Mediated Signaling Associated with Growth Regulation in Human Cells from Pulmonary Adenocarcinoma and Small Airway Epithelia," International Journal of Oncology, Vol. 27, No. 1, 2005, pp. 155-160.

[26] N. Saito, U. Kikkawa and Y. Nishizuka, "The Family of Protein Kinase C and Membrane Lipid Mediators," Journal of Diabetes and Its Complications, Vol. 16, No. 1, 2002, pp. 4-8. doi:10.1016/S1056-8727(01)002008

[27] M. Y. Choi, H. S. Song, H. S. Hur and S. Sim, "Whitening Activity of Luteolin Related to the Inhibition of cAMP Pathway in Alpha-MSH Stimulated B16 Melanoma Cells," Archives of Pharmacal Research, Vol. 31, No. 9, 2008, pp. 1166-1171. doi:10.1007/s12272-009-1309-8

[28] M. Perluigi, F. De-Marco, C. Foppoli, R. Coccia, C. Blarzino, M. L. Marcante and C. Cini, "Tyrosinase Protects Human Melanocytes from ROS-Generating Compounds," Biochemical and Biophysical Research Communications, Vol. 305, No. 2, 2003, pp. 250-256.

[29] J. Yamakoshi, F. Otsuka, A. Sano, S. Tokutake, M. Saito, M. Kikuchi and Y. Kubota, "Lightening Effect on Ultraviolet-Induced Pigmentation of Guinea Pig Skin by Oral Administration of a Proanthocyanidin Rich Extract from Grape Seeds," Pigment Cell Research, Vol. 16, No. 6, 2003, pp. 629-638. doi:10.1046/j.16000749.2003.00093.x

[30] B. Shen, R. G. Jensen and H. J. Bohnert, "Mannitol Protects against Oxidation by Hydroxyl Radicals," Plant Physiology, Vol. 115, No. 2, 1997, pp. 527-532.

[31] D. J. Tobin and R. P. Graying, "Gerontobiology of the Hair Follicle Pigmentary Unit," Experimental Gerontology, Vol. 36, No. 1, 2001, pp. 29-54.

[32] T. Horikawa, D. A. Norris, T. W. Johnson, T. Zekman, N. Dunscomb, S. D. Bennion, R. L. Jackson and J. G. Morelli, "DOPA-Negative Melanocytes in the Outer Root Sheath of Human Hair Follicles Express Premelanosomal Antigens but Not a Melanosomal Antigen or the Melanosome-Associated Glycoproteins Tyrosinase, TRP-1, and TRP-2," Journal of Investigative Dermatology, Vol. 106, No. 1, 1996, pp. 28-35. doi:10.1111/1523-1747.ep12326989

[33] H. Matsuda, Y. Kawaguchi, M. Yamazaki, N. Hirata, S. Naruto, Y. Asanuma, T. Kaihatsu and M. Kubo, "Melanogenesis Stimulation in Murine B16 Melanoma Cells by Pipernigrum Leaf Extract and Its Lignan Constituents," Biological Pharmaceutical Bulletin, Vol. 27, No. 10, 2004, pp. 1611-1616. doi:10.1248/bpb.27.1611

[34] M. J. Berridge, P. Lipp and M. D. Bootman, "The Versatility and Universality of Calcium Signaling," Nature Reviews Molecular Cell Biology, Vol. 1, No. 1, 2000, pp. 11-21. doi: $10.1038 / 35036035$

[35] R. F. Irvine and S. J. Michael, "Back in the Water: The
Return of the Inositol Phosphates," Nature Reviews Molecular Cell Biology, Vol. 2, No. 1, 2001, pp. 327-338. doi:10.1038/35073015

[36] M. J. Iqbal, A. J. Afzal, S. Yaegashi, E. Ruben, K. Triwitayakorn, V. N. Njiti, R. Ahsan, A. J. Wood and D. A. Lightfoot, "A Pyramid of Loci for Partial Resistance to Fusarium solani f. sp. Glycines Maintains myo-Inositol1-phosphate Synthase Expression in Soybean Roots," Theoretical and Applied Genetics, Vol. 105, 2002, pp. 1115-1123. doi:10.1007/s00122-002-0987-0

[37] R. M. Deranieh and M. L. Greenberg, "Cellular Consequences of Inositol Depletion," Biochemical Society Transactions, Vol. 37, No. 5, 2009, pp. 1099-1103. doi:10.1042/BST0371099

[38] J. Larner, "D-Chiro-Inositol-Its Functional Role in Insulin Action and Its Deficit in Insulin Resistance," International Journal of Experimental Diabetes Research, Vol. 3, No. 3, 2002, pp. 47-60. doi:10.1080/15604280212528

[39] P. A. Brex, B. Gomez-Anson, G. J. Parker, P. D. Molyneux, K. A. Miszkiel, G. J. Barker, D. G. MacManus, C. A. Davie and G. T. Plant, "Proton NMR Spectroscopy in Clinically Isolated Syndromes Suggestive of Multiple Sclerosis," Journal of the Neurological Sciences, Vol. 166, No. 1, 1999, pp. 16-22. doi:10.1016/S0022-510X(99)00105-7

[40] J. McLaurin, T. Franklin, A. Chakrabartty and P. E. Fraser, "Phosphatidylinositol and Inositol Involvement in Alzheimer Amyloid- $\beta$ Fibril Growth and Arrest," Journal of Molecular Biology, Vol. 278, No. 1, 1998, pp. 183-194. doi:10.1006/jmbi.1998.1677

[41] T. P. Thomas, F. Porcellati, K. Kato, M. J. Stevens, W. R. Sherman and D. A. Greene, "Effects of Glucose on Sorbitol Pathway Activation, Cellular Redox, and Metabolism of myo-Inositol, Phosphoinositide, and Diacylglycerol in Cultured Human Retinal Pigment Epithelial Cells," Journal of Clinical Investigation, Vol. 93, No. 6, 1994, pp. 2718-2724. doi:10.1172/JCI117286

[42] B. C. Saha and F. M. Racine, "Biotechnological Production of Mannitol and Its Applications," Applied Microbiology and Biotechnology, Vol. 89, No. 4, 2011, pp. 879891. doi:10.1007/s00253-010-2979-3

[43] W. Soetaert, K. Buchholz and E. J. Vandamme, "Production of D-Mannitol and D-Lactic Acid by Fermentation with Leuconostoc mesenteroides," Agrofood Industry HiTech, Vol. 6, 1995, pp. 41-44. doi:10.1002/bit.10638

[44] S. I. Rapoport, "Advances in Osmotic Opening of the Blood-Brain Barrier to Enhance CNS Chemotherapy," Expert Opinion on Investigational Drugs, Vol. 10, No. 10, 2001, pp. 1809-1818. doi:10.1517/13543784.10.10.1809

[45] G. Miller, "Drug Targeting. Breaking Down Barriers," Science, Vol. 297, No. 5584, 2002, pp. 1116-1118. doi:10.1126/science.297.5584.1116

[46] J. C. Johnson, "Sugar Alcohols and Derivatives," In: J. C. Johnson, Ed., Specialized Sugars for the Food Industry, Noyes Data Corporation, New Jersey, 1976, pp. 313-323. 